\title{
Nitrate and Nitrite in Health and Disease
}

\author{
Linsha Ma, Liang Hu, Xiaoyu Feng, Songlin Wang* \\ Salivary Gland Disease Center and Beijing Key Laboratory of Tooth Regeneration and Function Reconstruction, \\ Capital Medical University, Beijing 100069, China
}

[Received November 12, 2017; Revised December 6, 2017; Accepted December 7, 2017]

\begin{abstract}
The source of dietary nitrate $\left(\mathrm{NO}_{3}\right)$ is mainly green, leafy vegetables, partially absorbed into blood through intestinal mucosa. The recycled nitrate is reabsorbed and concentrated by the salivary glands and then secreted into saliva. In 2012, sialin was first discovered as the mammalian membrane nitrate transporter in salivary glands and plays a key role in circulation of inorganic nitrate, providing a scientific basis for further investigation into the circulation and functions of nitrate. Dietary nitrate can be converted to nitrite $\left(\mathrm{NO}_{2}\right)$ by oral commensal bacteria under the tongue or in the stomach, following which nitrite is converted to nitric oxide (NO) through non-enzymatic synthesis. Previously, nitrate and nitrite were thought to be carcinogenic due to the potential formation of nitrogen compounds, whereas the beneficial functions of $\mathrm{NO}_{3}-\mathrm{NO}_{2}-\mathrm{NO}$ pathway were ignored. Under conditions of hypoxia and ischemia, the production of endogenous NO from L-arginine is inhibited, while the activity of exogenous $\mathrm{NO}_{3}-\mathrm{NO}_{2}{ }^{-}-\mathrm{NO}$ is enhanced. Recently, a greater amount of evidence has shown that nitrate and nitrite serve as a reservoir and perform positive biological NO-like functions. Therefore, exogenous dietary nitrate plays an important role in various physiological activities as an effective supplement of nitrite and NO in human body. Here we generally review the source, circulation and bio-functions of dietary nitrate.
\end{abstract}

Key words: dietary nitrate, $\mathrm{NO}_{3}=\mathrm{NO}_{2}{ }^{-}-\mathrm{NO}$ pathway, circulation, sialin

Nitrate $\left(\mathrm{NO}_{3}\right)$ and nitrite $\left(\mathrm{NO}_{2}\right)$ widely exist in water, soil, air, and plants [1]. The main source of absorbed nitrate in the body is food, with green vegetables contributing the major portion. Although nitrates are stable, dietary nitrate is converted to nitrite through a non-enzymatic process and nitric oxide (NO) by symbiotic bacteria in the oral cavity and stomach, therefore performing physiological NO functions. NO, the metabolic product of dietary nitrate, plays an important role in protecting the cardiovascular system and gastric mucosa, and in metabolic diseases [2,3]. Endogenous NO is derived from the arginine pathway and is regulated by nitric oxide synthase (NOS) and its redox state. However, under conditions of hypoxia and ischemia, the activity of NOS is down-regulated resulting in a decreased production of endogenous NO. The skeletal muscle cells of rats were found to be capable of nitrate intake from peripheral blood, following which nitrate was deoxidized to NO by xanthine oxidation-reductase pathway, thereby increasing blood flow rate and enhancing metabolism [4]. Dietary nitrate served as an effective donor of $\mathrm{NO}$, and the possible functions of NO from dietary nitrate are being widely studied.

Nitrate was thought to be harmful due to the potential production of carcinogenic nitrosamines under certain conditions such as an acidic stomach. Nitrosamines were reported to be related to esophageal cancer, gastric cancer, colon cancer, and other tumors $[5,6]$. Thus, the World Health Organization (WHO) recommended the upper limit of concentration of daily nitrate and nitrite uptake to be $3.7 \mathrm{mg} / \mathrm{kg}$ and $0.06-0.07 \mathrm{mg} / \mathrm{kg}$, respectively [4]. However, recent epidemiological investigations of nitrates and tumors have shown that no clear evidence has verified that dietary nitrate could increase the occurrence

*Correspondence should be addressed to: Dr. Songlin Wang, Salivary Gland Disease Center and Beijing Key Laboratory of Tooth Regeneration and Function Reconstruction, Capital Medical University, Beijing, China. Email: slwang@ccmu.edu.cn.

Copyright: ( $2017 \mathrm{Ma} \mathrm{L}$ et al. This is an open-access article distributed under the terms of the Creative Commons Attribution License, which permits unrestricted use, distribution, and reproduction in any medium, provided the original author and source are credited. 
of tumors [7]. In 2012, sialin was first reported as a nitrate cell membrane transporter which played an important role in the circulation of dietary nitrate. Nitrate is actively transported by sialin in salivary glands, concentrated in saliva, and then secreted into the oral cavity, after which it reenters body circulation through the stomach and intestine [8]. As dietary nitrate is converted to NO by oral and stomach bacteria through non-enzymatic synthesis, nitrate could be considered indispensable in physiological activities.

\section{Source of nitrate and nitrite}

Systemic circulating nitrate is mainly obtained from two sources, diet and oxidation of endogenous NO, which correspond to exogenous and endogenous nitrates, respectively [9]. Exogenous sources of nitrate for human intake are primarily foods which account for approximately $60 \%-80 \%$ of the total nitrate intake [10]. In keeping with recent reports, vegetables, especially green leafy vegetables, such as spinach and beetroot contain an abundance of nitrate [11], which contributes nearly $80 \%$ $90 \%$ of the total dietary nitrate [12]. Other sources of nitrate are drinking water $(15 \%-20 \%)$ and other foods, including animal-based products $(10 \%-15 \%)$ [13].

With respect to nitrite, approximately $80 \%-85 \%$ [9, 14] of total systemic nitrite is obtained through endogenous conversion from nitrate [15]. Nearly 93\% nitrite is converted from nitrate [16]. An individual consumes about 1.2-3.0 mg nitrite every day [17]. The other sources of nitrite are oxidation of endogenous NO and exogenous nutritional sources (cured meats comprise $4.8 \%$ and vegetables account for 2.2\%) [10]. Exogenous nitrite is almost completely absorbed in the duodenum and jejunum [18]. Most systemic circulating nitrite is converted to $\mathrm{NO}$ and serves as a relatively stable reservoir of NO.

\section{Distribution and conversion of nitrate and nitrite}

Nitrate and nitrite exist widely in the human body, while the distribution is quite different. Volunteers receiving water labeled nitrogen $13\left({ }^{13} \mathrm{NO}_{3}{ }^{-}\right)$were found that nitrate did not rapidly absorbed into blood from the stomach but rather stably existed in the intestine. While after intravenous administration of ${ }^{13} \mathrm{NO}_{3}^{-}$, the distribution of nitrate was active in heart, reaching peak concentration of about $3 \%$ percent of total nitrate at 2 minutes, then fell rapidly in the next 2 minutes $[19,20]$.

Systemic nitrate and nitrite was circulating among blood, saliva and tissues, after a rich nitrate diet, the nitrate was absorbed and the plasma level peak up in 1530 minutes with a half-life of about 5-8 hours [3, 21, 22]. As the concentration of nitrate was about 10 times of that in plasma, saliva contained large amount of total nitrate
[23]. The active ingestion ability of nitrate in different organs differs greatly, possibly depending on the expression of nitrate transporter protein-sialin $[8,24]$.

Nitrite in blood soon converts to nitrate with half-life about $110 \mathrm{~s}$, while nitrite in plasma is relatively stable with half-life about 20-30 mins [4, 25-28]. Normal plasma levels of nitrite are 50-100 $\mathrm{nM}$ and increase 4-5 times after a nitrate-rich meal, in which process numerous proteins and enzymes in blood and tissues catalyze the reduction of nitrate to nitrite $[2,29]$. The conversion of nitrate to nitrite was an enzymatic process, while the conversion of nitrite to NO was a non-enzymatic process.

\section{Circulation of nitrate and nitrite}

The salivary glands and oral bacteria play an essential role in the circulation and conversion process of exogenous $\mathrm{NO}_{3}{ }^{-}-\mathrm{NO}_{2}-\mathrm{NO}$ pathway. Dietary nitrate is absorbed almost entirely owing to its bioavailability in the stomach and the small intestine, and about $75 \%$ is excreted in urine, while the remaining amount is reabsorbed in the kidney, by biliary and in salivary glands $[3,30,31]$. Under normal conditions, up to $25 \%$ of recycled nitrate can be found in salivary glands, where the nitrate concentration reached 10 times that of the plasma [32]. In 2012, based on the organ model of salivary glands, sialin was discovered as the nitrate transporter in mammalian cell membranes, which provided the scientific foundation for the study of the biological effect and metabolism of nitrates in the body $[8,24,33]$ Approximately $5 \%-7 \%$ of dietary nitrate is converted to nitrite in the oral cavity by commensal facultative anaerobic bacteria located in the deep crypts of the posterior part of the tongue $[34,35]$. Thereafter, most nitrite is converted to nitric oxide in the stomach and absorbed systematically (Fig. 1).

\section{Function of nitrate and nitrite}

Under conditions of hypoxia and ischemia, the production of endogenous NO from L-arginine is inhibited. On the contrary, the activity of exogenous $\mathrm{NO}_{3}^{-}-\mathrm{NO}_{2}{ }^{-} \mathrm{NO}$ is enhanced. Thus, dietary nitrate and nitrite serve as effective donors of NO under conditions of hypoxia and ischemia [34]. Nitrate and nitrite are used as food additives in processed food where they act as preservatives by inhibiting the growth of microorganisms, notably Clostridium botulinum. Besides the direct antimicrobial effect of nitrite, the physiological effects of nitrogen species including inorganic nitrate and nitrite have been reported recently.

When dietary nitrate is not available, the excretion of total nitrate calculated in health volunteers was much larger than the amount of intake, indicating that nitrate and nitrite could be formed by endogenous synthesis. The 
endogenous production of nitrate was mainly in intestine mucosa tissues [36]. Nitrate performs physiological functions in various systemic activities, including blood pressure reduction, platelet aggregation inhibition, and vessel protective effect - functions similar to those of $\mathrm{NO}$ $[3,37]$. Nitrate prevents ischemic heart disease by increasing epicardial blood flow through vasodilation, decreasing vascular resistance, blunting coronary steal, and reducing preload [38]. Dietary nitrate $(10 \mathrm{mmol} / \mathrm{L}$ soldium nitrate in drinking water) can partly improve agerelated hypertension and metabolic activities in mice through a decrease of endogenous NO generation via inhibition of NADPH oxidase and modulation of angiotensin (ANG) II receptor expression [39].
Furthermore, inorganic nitrates suppress $(15 \mathrm{mmol} / \mathrm{L}$ $\mathrm{KNO}_{3}$ ) acute and chronic inflammation by raising the neutrophil count, which may reduce the occurrence of atheromatous plaque [40]. Moreover, a long-term dietary nitrate and nitrite deficiency experiment showed that mice would suffer from metabolic syndrome, endothelial dysfunction, and cardiovascular death after 22 months of a low-nitrite/nitrate diet [41]. Inorganic nitrate performs functions of decreasing blood pressure and improving myocardial ischemia by enhancing epithelial cell activity and diastole blood vessels, and reducing platelet aggregation [42].

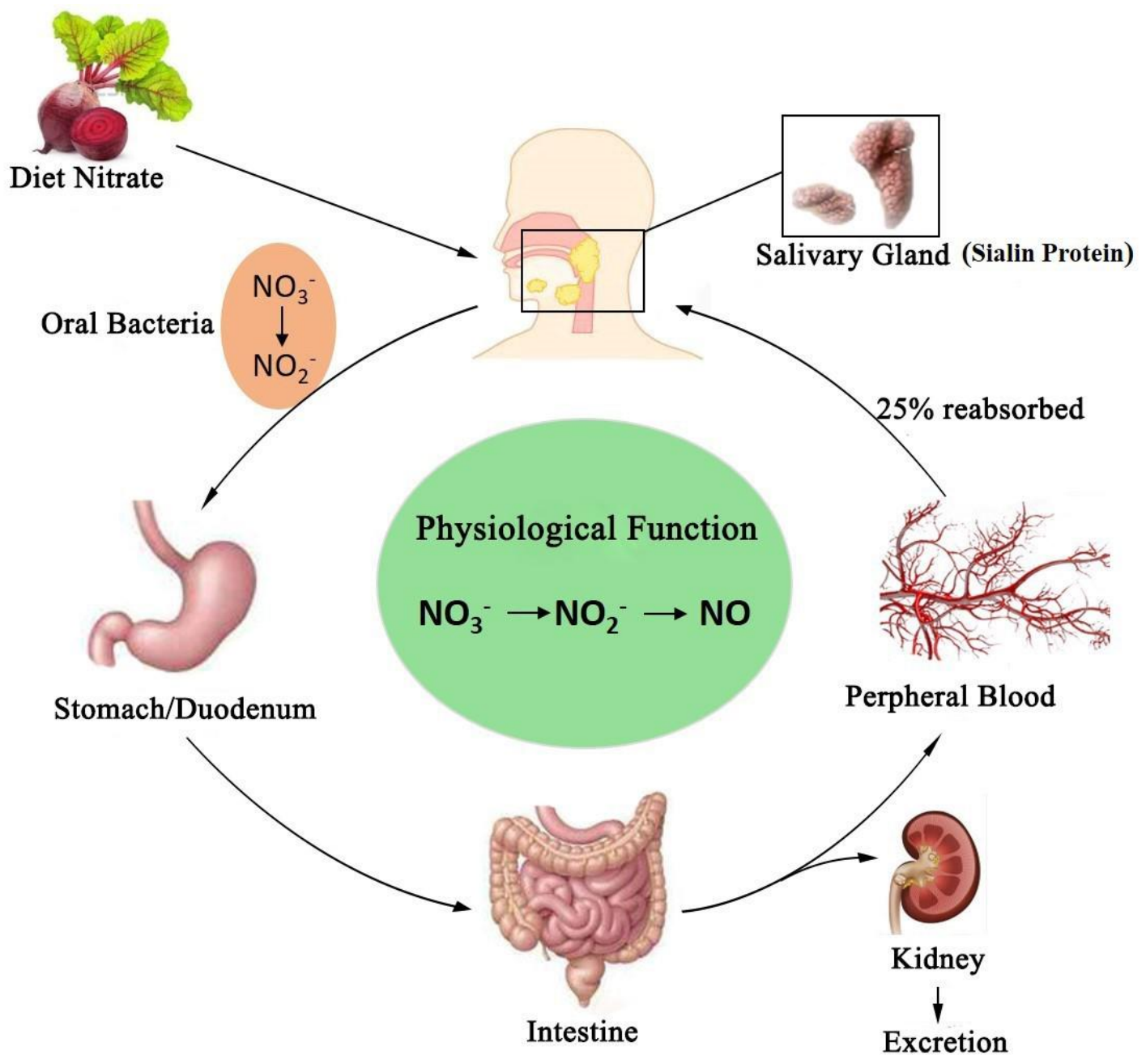

Figure 1. Circulation of nitrate in the body. The recycling of dietary nitrate is mainly in salivary glands, where sialin plays a key role in active transport and concentration of nitrate. Part of the nitrate is converted to nitrite by oral bacteria and subsequently absorbed in the stomach and intestine. Nearly $25 \%$ of circulating nitrate is reabsorbed by the salivary glands, whereas the majority is excreted by the kidneys. Nitrate performs physiological functions through the exogenous $\mathrm{NO}_{3}{ }^{-}-\mathrm{NO}_{2}-\mathrm{NO}$ pathway. $\mathrm{NO}$, nitric oxide; $\mathrm{NO}_{2}^{-}$, nitrite; $\mathrm{NO}_{3}^{-}$, nitrate. 
Nitrates secreted from saliva protect against gastric ulcers by promoting gastric NO expression and stimulating concomitant mucus formation [43]. Stressinduced gastric damage was reported with a water immersion-restraint stress (WIRS) assay in a rat model. Results showed that stress promotes salivary nitrate secretion and nitrite formation in health volunteers, and that exogenous nitrate administration $\left(5 \mathrm{mmol} / \mathrm{L} \mathrm{NaNO}_{3}\right)$ recovered gastric mucosal blood flow and introgastric $\mathrm{NO}$ level, thereby rescuing the WIRS-induced gastric damage [44]. The concentration of bioactive NO in the stomach increased 50-fold after ingestion of dietary nitrate [45]. Meanwhile, the non-enzymatic production of NO from dietary nitrate $\left(0.1\right.$ or $\left.1 \mathrm{mmol} / \mathrm{kg} \quad \mathrm{NaNO}_{3}\right)$ could effectively alleviate diclofenac-induced stomach mucosa injury and improve the thickness of slime layer in the stomach [43].

NO could regulate metabolic disorder-induced cardiovascular diseases and other metabolic disease. Moreover, the synthesis of NO was reduced in obese mice [46]. Metabolic disorder-induced high blood pressure, insulin resistance, and carbohydrate tolerance were found in ENOS (endothelial nitric oxide synthase)-knockout mice [47]. Dietary nitrate effectively supplements NO by the activated exogenous $\mathrm{NO}_{3}^{-}-\mathrm{NO}_{2}{ }^{-}-\mathrm{NO}$ pathway under conditions of hypoxia. With a continuous 3-day supplement of $0.1 \mathrm{mmol} / \mathrm{kg}$ sodium nitrate pre-exercise, the oxygen consumed was reduced to an average of 5\% [48]. Besides, nitrate enhanced the exercise tolerance of health volunteers by NO-cGMP-PPAR pathway and increased the metabolism of fatty acid in skeletal muscle cells [49]. Exogenous nitrate $\left(0.7 \mathrm{mmol} / \mathrm{L} \mathrm{NaNO}_{3}\right)$ could active the cGMP pathway in mice and promote the conversion of white adipose to brown adipose, therefore enhancing fat metabolism and decreasing body weight [50]. As metabolic diseases were mostly accompanied with NO synthetic disorder, the supplement of exogenous NO from dietary nitrate could partially alleviate metabolic diseases. Therefore, exogenous dietary nitrate is an essential element in the human body and plays an important role in various physiological activities as an effective supplement of nitrite and NO.

\section{Safety of nitrate and nitrite}

Previously nitrate and nitrite were considered as precursors of N-nitroso compounds that were classified as human carcinogens. Nitrate was converted to nitrite and then gets into the stomach, where the condition of low $\mathrm{pH}$ promotes the conversion of nitrite to reactive nitrous acid [51]. Besides under conditions of inflammation and bacteria (Helicobacter Pylori), the formation of nitrate related nitrosamine was enhanced. Patients with achlorhydria and bacterial overgrowth were at high risk of developing gastric cancer possibly because of the formation of nitrosamine [52, 53]. However, this process would be weakened by polyphenols and other antioxidants such as vitamin C. With enough amounts of antioxidants as vitamin $\mathrm{C}$, the nitrosylation of secondary amine through nitrite was inhibited [54, 55].

The International Agency for Research on Cancer (IARC) has concluded that there was no substantial evidence implicating nitrates as animal carcinogens in 2010 [56]. Moreover, in recent epidemiological investigations, dietary nitrate showed no association with gastric cancer or esophageal cancer in humans [7, 57]. Some research even showed that nitrate could decrease the occurrence of gastric cancer $[11,58]$, possibly because the main source of dietary nitrate are vegetables, which contain a large amount of fiber, vitamin $\mathrm{C}$, and other reductants. An investigation in Korea, where the intake of dietary nitrates (390-742 $\mathrm{mg}$ /day) is considerably higher than that of European countries $(52-156 \mathrm{mg} /$ day) and China (422.8 mg/day), showed that no correlation was found between high intake of nitrate and cancer [59]. Besides, the safety of high dietary nitrate $(91 \mathrm{~g} / \mathrm{L}$ potassium nitrate) supply was identified in a miniature pig model. Liver and kidney tissues were checked after highdose nitrate feeding for 2 years, and no observed systemic toxicity or damage was found in miniature pigs [60]. With 17 continuous weeks of $85 \mathrm{mg} / \mathrm{L}$ sodium nitrate-water supplement, increased insulin sensitivity, decreased plasma IL-10 level, and tendency of pro-long lifetime were found without body injury in these mice [61].

The association of nitrite with cancer seems conflicted [11]. The correlation between nitrite and gastric cancer is contradictory in different epidemiological surveys [57]. In 2011, carrying out a large cohort study including approximately 50000 individuals, followed up on for almost 10 years, Cross and his teammates concluded that nitrate and nitrite were not associated with esophageal or gastric cancer, whereas positive associations were found between red meat intake and esophageal squamous cell carcinoma [62]. Some epidemiological studies use processed or smoked meat as a source of exogenous nitrite ignoring complex compounds such as nitrosamines in such foods, resulting in lack of uniformity and scientific accuracy in conclusions. Therefore, association of exogenous nitrite with cancer seems less likely because large amounts of nitrite are formed endogenously. The nitrite concentration in saliva may rise as high as $72 \mathrm{mg} / \mathrm{L}$ after consumption of nitrate equivalent to $200 \mathrm{~g}$ of spinach [63]. Besides, people are in contact with nitrosamine in many circumstances, such as through smoke, beer, water, working environment, especially cigarettes which contain about 100-1000 times the level of nitrosamine in the daily diet. 
Methemoglobinemia was found to be caused on ingestion of excessive nitrite [64], whereas ingestion of excessive nitrate did not lead to the disorder. A study in America showed that even though the mother ingested a large amount of nitrate, the baby would not get methemoglobinemia through breast feeding [65]. On the other hand, dietary nitrate, the source of which is mostly vegetables, which contain a large amount of antioxidants, effectively decreases the occurrence of methemoglobinemia [3].

\section{Clinical application of nitrate and nitrite}

Under conditions of illness or senescence, the activity of eNOS was reduced and the production of NO was decreased, as reported [46, 66, 67], thus indicating exogenous source of NO supplement might have a potential therapeutic treatment for patients undergoing illness or senescence. Nitrate was reported could lower blood pressure in health volunteers [68] and established in several experiments in human trials [69]. The aortic pulse wave velocity was improved, and the platelet-monocyte aggregates reduced in nitrate supplemental patients which resulting in decreased blood pressure [70]. Whilst with positive clinical trials, negative results were reported showing no significant effect was found in lowing blood pressure with nitrate supplement [71, 72]. The reason of these complex results was uncertain and more clinical trials were needed for further research.

Although many positive effects were found in animal models, the clinical usage of nitrate was quite limited. In recent years, nitrate-rich fruit and vegetable drinks especially beetroot drinks, Biotta veggie drink (Biotta ${ }^{\circledR}$, Switzerland) [73], and BEET-IT (James White Drinks, Ipswich, UK) [74-76] have become popular. With increasing awareness on nitrates, nitrates and nitraterelated products are being accepted.

\section{Conclusion}

As part of their daily diet, people ingest inorganic nitrate mostly through green, leafy vegetables. Apart from their negatives, dietary nitrate and nitrite have been reported as exogenous donors of biological NO, playing an important role in physiological activity. Furthermore, dietary nitrate supplements seem to have potential protective effect for body balance, improvement of disorders (stroke, myocardial infarction, systemic and pulmonary hypertension, etc.), and in alleviation of gastric ulcers. Normal dietary nitrate and nitrite showed no harm to human health and no confirmed evidence stated the explicit association of dietary nitrate and cancer. Most existing research on nitrite and tumors ignored the complicated compounds in target foods, resulting in contradictory conclusions among researchers. Considering the various protective effects, other than the formal harmful suspects, dietary nitrate and nitrite play an important role in physiological functions through the provision of non-enzymatic NO. With a new understanding of nitrates and nitrites, their biological functions and applications need further investigation in the future.

\section{Acknowledgments}

This study was supported by grant from the National Natural Science Foundation of China (91649124) and grants from Beijing Municipality Government grants (Beijing Scholar Program- PXM2016_014226_000034, PXM2016_014226_000006, PXM2015_014226_o00116, PXM2015_014226_000055, PXM2015_014226_000052, PXM2014_014226_000048, PXM2014_014226_000013, PXM2014_014226_000053, PXM2013_014226_000055, Z121100005212004, PXM2013_014226_07_000080, PXM2013_014226_000021, and TJSHG201310025005).

\section{References}

[1] Gassara F, Kouassi AP, Brar SK, Belkacemi K (2016). Green Alternatives to Nitrates and Nitrites in Meatbased Products-A Review. Crit Rev Food Sci Nutr, 56:2133-2148.

[2] Govoni M, Jansson EA, Weitzberg E, Lundberg JO (2008). The increase in plasma nitrite after a dietary nitrate load is markedly attenuated by an antibacterial mouthwash. Nitric Oxide, 19:333-337.

[3] Lundberg JO, Carlstrom M, Larsen FJ, Weitzberg E (2011). Roles of dietary inorganic nitrate in cardiovascular health and disease. Cardiovasc Res, 89:525-532.

[4] Weitzberg E, Lundberg JO (2013). Novel aspects of dietary nitrate and human health. Annu Rev Nutr, 33:129-159.

[5] Bedale W, Sindelar JJ, Milkowski AL (2016). Dietary nitrate and nitrite: Benefits, risks, and evolving perceptions. Meat Sci, 120:85-92.

[6] Park JE, Seo JE, Lee JY, Kwon H (2015). Distribution of Seven N-Nitrosamines in Food. Toxicol Res, 31:279-288.

[7] Bryan NS, Alexander DD, Coughlin JR, Milkowski AL, Boffetta P (2012). Ingested nitrate and nitrite and stomach cancer risk: an updated review. Food Chem Toxicol, 50:3646-3665.

[8] Qin L, Liu X, Sun Q, Fan Z, Xia D, Ding G, et al. (2012). Sialin (SLC17A5) functions as a nitrate transporter in the plasma membrane. Proc Natl Acad Sci U S A, 109:13434-13439.

[9] Lundberg JO, Weitzberg E (2013). Biology of nitrogen oxides in the gastrointestinal tract. Gut, 62:616-629.

[10] Archer DL (2002). Evidence that ingested nitrate and nitrite are beneficial to health. J Food Prot, 65:872- 
875.

[11] Song P, Wu L, Guan W (2015). Dietary Nitrates, Nitrites, and Nitrosamines Intake and the Risk of Gastric Cancer: A Meta-Analysis. Nutrients, 7:98729895.

[12] Knight TM, Forman D, Al-Dabbagh SA, Doll R (1987). Estimation of dietary intake of nitrate and nitrite in Great Britain. Food Chem Toxicol, 25:277285.

[13] Skibsted LH (2011). Nitric oxide and quality and safety of muscle based foods. Nitric Oxide, 24:176183.

[14] Butler A (2015). Nitrites and nitrates in the human diet: Carcinogens or beneficial hypotensive agents? J Ethnopharmacol, 167:105-107.

[15] Mensinga TT, Speijers GJ, Meulenbelt J (2003). Health implications of exposure to environmental nitrogenous compounds. Toxicol Rev, 22:41-51.

[16] Sindelar JJ, Milkowski AL (2012). Human safety controversies surrounding nitrate and nitrite in the diet. Nitric Oxide, 26:259-266.

[17] Sobsey MD, Bartram S (2003). Water quality and health in the new millennium: the role of the World Health Organization Guidelines for Drinking-Water Quality. Forum Nutr, 56:396-405.

[18] Hunault CC, van Velzen AG, Sips AJ, Schothorst RC, Meulenbelt J (2009). Bioavailability of sodium nitrite from an aqueous solution in healthy adults. Toxicol Lett, 190:48-53.

[19] Witter JP, Gatley SJ, Balish E (1979). Distribution of nitrogen-13 from labeled nitrate (13No3-) in humans and rats. Science, 204:411-413.

[20] Witter JP, Balish E, Gatley SJ (1979). Distribution of nitrogen-13 from labeled nitrate and nitrite in germfree and conventional-flora rats. Appl Environ Microbiol, 38:870-878.

[21] Tannenbaum SR (1979). Nitrate and nitrite: origin in humans. Science, 205:1332, 1334-1337.

[22] Yoshida K, Kasama K, Kitabatake M, Okuda M, Imai M (1980). Metabolic fate of nitric oxide. Int Arch Occup Environ Health, 46:71-77.

[23] Xia DS, Deng DJ, Wang SL (2003). Destruction of parotid glands affects nitrate and nitrite metabolism. J Dent Res, 82:101-105.

[24] Qu XM, Wu ZF, Pang BX, Jin LY, Qin LZ, Wang SL (2016). From Nitrate to Nitric Oxide: The Role of Salivary Glands and Oral Bacteria. J Dent Res, 95:1452-1456.

[25] Kelm M (1999). Nitric oxide metabolism and breakdown. Biochim Biophys Acta, 1411:273-289.

[26] Kelm M (2003). The L-arginine-nitric oxide pathway in hypertension. Curr Hypertens Rep, 5:80-86.

[27] Kelm M, Preik-Steinhoff H, Preik M, Strauer BE (1999). Serum nitrite sensitively reflects endothelial NO formation in human forearm vasculature: evidence for biochemical assessment of the endothelial Larginine-NO pathway. Cardiovasc Res, 41:765-772.

[28] Keymel S, Rassaf T, Kelm M (2006). Nitrite in action: a commentary on "Low-dose intravenous nitrite improves hemodynamics in a canine model of acute pulmonary thromboembolism". Free Radic Biol Med, 41:1750-1752.

[29] Zweier JL, Li H, Samouilov A, Liu X (2010). Mechanisms of nitrite reduction to nitric oxide in the heart and vessel wall. Nitric Oxide, 22:83-90.

[30] Fritsch P, de Saint Blanquat G, Klein D (1985). Excretion of nitrates and nitrites in saliva and bile in the dog. Food Chem Toxicol, 23:655-659.

[31] Kahn T, Bosch J, Levitt MF, Goldstein MH (1975). Effect of sodium nitrate loading on electrolyte transport by the renal tubule. Am J Physiol, 229:746753.

[32] Spiegelhalder B, Eisenbrand G, Preussmann R (1976). Influence of dietary nitrate on nitrite content of human saliva: possible relevance to in vivo formation of $\mathrm{N}$ nitroso compounds. Food Cosmet Toxicol, 14:545548.

[33] Lundberg JO (2012). Nitrate transport in salivary glands with implications for NO homeostasis. Proc Natl Acad Sci U S A, 109:13144-13145.

[34] Bryan NS, Ivy JL (2015). Inorganic nitrite and nitrate: evidence to support consideration as dietary nutrients. Nutr Res, 35:643-654.

[35] Gaston B, Drazen JM, Loscalzo J, Stamler JS (1994). The biology of nitrogen oxides in the airways. Am J Respir Crit Care Med, 149:538-551.

[36] Tannenbaum SR, Fett D, Young VR, Land PD, Bruce WR (1978). Nitrite and nitrate are formed by endogenous synthesis in the human intestine. Science, 200:1487-1489.

[37] Kapil V, Weitzberg E, Lundberg JO, Ahluwalia A (2014). Clinical evidence demonstrating the utility of inorganic nitrate in cardiovascular health. Nitric Oxide, 38:45-57.

[38] Pragani MA, Desai KP, Morrone D, Sidhu MS, Boden WE (2017). The Role of Nitrates in the Management of Stable Ischemic Heart Disease: A Review of the Current Evidence and Guidelines. Rev Cardiovasc Med, 18:14-20.

[39] Hezel M, Peleli M, Liu M, Zollbrecht C, Jensen BL, Checa A, et al. (2016). Dietary nitrate improves agerelated hypertension and metabolic abnormalities in rats via modulation of angiotensin II receptor signaling and inhibition of superoxide generation. Free Radic Biol Med, 99:87-98.

[40] Khambata RS, Ghosh SM, Rathod KS, Thevathasan T, Filomena F, Xiao Q, et al. (2017). Antiinflammatory actions of inorganic nitrate stabilize the atherosclerotic plaque. Proc Natl Acad Sci U S A, 114:E550-E559.

[41] Kina-Tanada M, Sakanashi M, Tanimoto A, Kaname T, Matsuzaki T, Noguchi K, et al. (2017). Long-term dietary nitrite and nitrate deficiency causes the metabolic syndrome, endothelial dysfunction and cardiovascular death in mice. Diabetologia, 60:11381151.

[42] Machha A, Schechter AN (2011). Dietary nitrite and nitrate: a review of potential mechanisms of cardiovascular benefits. Eur J Nutr, 50:293-303.

[43] Jansson EA, Petersson J, Reinders C, Sobko T, Bjorne $\mathrm{H}$, Phillipson M, et al. (2007). Protection from 
nonsteroidal anti-inflammatory drug (NSAID)induced gastric ulcers by dietary nitrate. Free Radic Biol Med, 42:510-518.

[44] Jin L, Qin L, Xia D, Liu X, Fan Z, Zhang C, et al. (2013). Active secretion and protective effect of salivary nitrate against stress in human volunteers and rats. Free Radic Biol Med, 57:61-67.

[45] Petersson J, Phillipson M, Jansson EA, Patzak A, Lundberg JO, Holm L (2007). Dietary nitrate increases gastric mucosal blood flow and mucosal defense. Am J Physiol Gastrointest Liver Physiol, 292:G718-724.

[46] Siervo M, Jackson SJ, Bluck LJ (2011). In-vivo nitric oxide synthesis is reduced in obese patients with metabolic syndrome: application of a novel stable isotopic method. J Hypertens, 29:1515-1527.

[47] Cook S, Hugli O, Egli M, Vollenweider P, Burcelin R, Nicod P, et al. (2003). Clustering of cardiovascular risk factors mimicking the human metabolic syndrome $\mathrm{X}$ in eNOS null mice. Swiss Med Wkly, 133:360-363.

[48] Jones AM (2014). Dietary nitrate supplementation and exercise performance. Sports Med, 44 Suppl 1:S35-45.

[49] Ashmore T, Roberts LD, Morash AJ, Kotwica AO, Finnerty J, West JA, et al. (2015). Nitrate enhances skeletal muscle fatty acid oxidation via a nitric oxidecGMP-PPAR-mediated mechanism. BMC Biol, 13:110.

[50] Roberts LD, Ashmore T, Kotwica AO, Murfitt SA, Fernandez BO, Feelisch M, et al. (2015). Inorganic nitrate promotes the browning of white adipose tissue through the nitrate-nitrite-nitric oxide pathway. Diabetes, 64:471-484.

[51] McKnight GM, Smith LM, Drummond RS, Duncan CW, Golden M, Benjamin N (1997). Chemical synthesis of nitric oxide in the stomach from dietary nitrate in humans. Gut, 40:211-214.

[52] Ruddell WS, Bone ES, Hill MJ, Blendis LM, Walters CL (1976). Gastric-juice nitrite. A risk factor for cancer in the hypochlorhydric stomach? Lancet, 2:1037-1039.

[53] Eisenbrand G, Adam B, Peter M, Malfertheiner P, Schlag P (1984). Formation of nitrite in gastric juice of patients with various gastric disorders after ingestion of a standard dose of nitrate--a possible risk factor in gastric carcinogenesis. IARC Sci Publ:963968.

[54] Weisburger JH (1977). Vitamin C and prevention of nitrosamine formation. Lancet, 2:607.

[55] Erkekoglu P, Baydar T (2010). Evaluation of the protective effect of ascorbic acid on nitrite- and nitrosamine-induced cytotoxicity and genotoxicity in human hepatoma line. Toxicol Mech Methods, 20:4552.

[56] Humans IWGotEoCRt (2010). IARC monographs on the evaluation of carcinogenic risks to humans. Ingested nitrate and nitrite, and cyanobacterial peptide toxins. IARC Monogr Eval Carcinog Risks Hum, 94:v-vii, 1-412.

[57] Jakszyn P, Gonzalez CA (2006). Nitrosamine and related food intake and gastric and oesophageal cancer risk: a systematic review of the epidemiological evidence. World J Gastroenterol, 12:4296-4303.

[58] Hernandez-Ramirez RU, Galvan-Portillo MV, Ward MH, Agudo A, Gonzalez CA, Onate-Ocana LF, et al. (2009). Dietary intake of polyphenols, nitrate and nitrite and gastric cancer risk in Mexico City. Int $\mathbf{J}$ Cancer, 125:1424-1430.

[59] Kim HJ, Lee SS, Choi BY, Kim MK (2007). Nitrate intake relative to antioxidant vitamin intake affects gastric cancer risk: a case-control study in Korea. Nutr Cancer, 59:185-191.

[60] Xia D, Qu X, Tran SD, Schmidt LL, Qin L, Zhang C, et al. (2015). Histological characteristics following a long-term nitrate-rich diet in miniature pigs with parotid atrophy. Int J Clin Exp Pathol, 8:6225-6234.

[61] Hezel MP, Liu M, Schiffer TA, Larsen FJ, Checa A, Wheelock CE, et al. (2015). Effects of long-term dietary nitrate supplementation in mice. Redox Biol, 5:234-242.

[62] Cross AJ, Freedman ND, Ren J, Ward MH, Hollenbeck AR, Schatzkin A, et al. (2011). Meat consumption and risk of esophageal and gastric cancer in a large prospective study. Am J Gastroenterol, 106:432-442.

[63] Chang AC, Yang TY, Riskowski GL (2013). Ascorbic acid, nitrate, and nitrite concentration relationship to the 24hour light/dark cycle for spinach grown in different conditions. Food Chem, 138:382-388.

[64] Katabami K, Hayakawa M, Gando S (2016). Severe Methemoglobinemia due to Sodium Nitrite Poisoning. Case Rep Emerg Med, 2016:9013816.

[65] Greer FR, Shannon M, American Academy of Pediatrics Committee on N, American Academy of Pediatrics Committee on Environmental H (2005). Infant methemoglobinemia: the role of dietary nitrate in food and water. Pediatrics, 116:784-786.

[66] Rogers SC, Zhang X, Azhar G, Luo S, Wei JY (2013). Exposure to high or low glucose levels accelerates the appearance of markers of endothelial cell senescence and induces dysregulation of nitric oxide synthase. $\mathbf{J}$ Gerontol A Biol Sci Med Sci, 68:1469-1481.

[67] Novensa L, Novella S, Medina P, Segarra G, Castillo N, Heras M, et al. (2011). Aging negatively affects estrogens-mediated effects on nitric oxide bioavailability by shifting ERalpha/ERbeta balance in female mice. PLoS One, 6:e25335.

[68] Kapil V, Milsom AB, Okorie M, Maleki-Toyserkani S, Akram F, Rehman F, et al. (2010). Inorganic nitrate supplementation lowers blood pressure in humans: role for nitrite-derived NO. Hypertension, 56:274-281.

[69] Gee LC, Ahluwalia A (2016). Dietary Nitrate Lowers Blood Pressure: Epidemiological, Pre-clinical Experimental and Clinical Trial Evidence. Curr Hypertens Rep, 18:17.

[70] Velmurugan S, Gan JM, Rathod KS, Khambata RS, Ghosh SM, Hartley A, et al. (2016). Dietary nitrate improves vascular function in patients with hypercholesterolemia: a randomized, double-blind, placebo-controlled study. Am J Clin Nutr, 103:25-38. [71] Bondonno CP, Liu AH, Croft KD, Ward NC, Yang X, Considine MJ, et al. (2014). Short-term effects of 
nitrate-rich green leafy vegetables on blood pressure and arterial stiffness in individuals with high-normal blood pressure. Free Radic Biol Med, 77:353-362.

[72] Kapil V, Khambata RS, Robertson A, Caulfield MJ, Ahluwalia A (2015). Dietary nitrate provides sustained blood pressure lowering in hypertensive patients: a randomized, phase 2, double-blind, placebocontrolled study. Hypertension, 65:320-327.

[73] Miller GD, Marsh AP, Dove RW, Beavers D, Presley T, Helms C, et al. (2012). Plasma nitrate and nitrite are increased by a high-nitrate supplement but not by high-nitrate foods in older adults. Nutr Res, 32:160168.

[74] Bondonno CP, Liu AH, Croft KD, Ward NC, Shinde
S, Moodley Y, et al. (2015). Absence of an effect of high nitrate intake from beetroot juice on blood pressure in treated hypertensive individuals: a randomized controlled trial. Am J Clin Nutr, 102:368375.

[75] Friis AL, Steenholt CB, Lokke A, Hansen M (2017). Dietary beetroot juice - effects on physical performance in COPD patients: a randomized controlled crossover trial. Int $\mathrm{J}$ Chron Obstruct Pulmon Dis, 12:1765-1773.

[76] Vaughan RA, Gannon NP, Carriker CR (2016). Nitrate-containing beetroot enhances myocyte metabolism and mitochondrial content. $\mathrm{J}$ Tradit Complement Med, 6:17-22. 